\title{
Carry Forward the "Two Bombs and One Satellite" Spirit, and Cultivate the Core Socialist Values of College Students
}

\author{
Pan Xiangchao \\ Mianyang Teacher 'College ,Marxism School, Mianyang, Sichuan, China. \\ email,605081866@qq.com
}

Keywords: "Two Bombs and One Satellite" Spirit; College students; The concept of socialist core values.

\begin{abstract}
The orientation of the values of college students is not only related to the future of every college student, but also to the fate of the Chinese nation. The spirit of " Two Bombs and One Satellite " is a powerful inspiration to young students, and the spirit of "two bullets and one star" has become an important source of cultivating the socialist core values of contemporary college students. We should strengthen the ideological and political work in colleges and universities through various channels, carry forward the spirit of " Two Bombs and One Satellite ", and foster the core socialist values of contemporary college students. It is of great significance to promote the self-consciousness of " Two Bombs and One Satellite " into college students.
\end{abstract}

\section{弘扬“两弹一星” 精神，培育大学生社会主义核心价值观 潘祥超 \\ 绵阳师范学院马克思主义学院, 绵阳, 四川, 中国 email,605081866@qq.com}

关键词: “两弹一星” 精神; 大学生; 社会主义核心价值体观

中文摘要. 大学生的价值观取向, 不仅关系到每一位大学生自身的前途, 而且关系到中华民 族的命运。“两弹一星” 精神对青年学子强烈的感召力, 使得 “两弹一星” 精神成为培育当 代大学生社会主义核心价值观的重要源泉。我们要通过多种途径加强高校思想政治工作, 弘 扬 “两弹一星” 精神, 培育当代大学生社会主义核心价值观。这对于促进 “两弹一星” 精神 内化为大学生的自觉行动, 有重要意义。

\section{1. 引言}

中共中央办公厅印发的《关于培育和践行社会主义核心价值观的意见》指出：“培育和 践行社会主义核心价值观要从小抓起、从学校抓起。……努力培养德智体美劳全面发展的社 会主义建设者和接班人。”习近平同志指出：“两弹一星” 精神是宝贵的精神财富, 一定要 一代代地传下去, 使之转化为不可限量的物质创造力。[1]深入研究 “两弹一星” 精神的内涵 和实质, 不断探讨 “两弹一星” 精神与社会主义核心价值观的契合之处, 用两弹一星精神加 强大学生社会主义核心价值观教育, 有十分重要的理论意义和实践价值。

\section{2. “两弹一星” 精神的科学内涵}

伟大的事业孕育伟大的精神。江泽民同志指出, 在为 “两弹一星” 事业进行的奋斗中, 广大研制工作者培育和发扬了一种崇高的精神, 这就是 “热爱祖国、无私奉献, 自力更生、 艰苦奋斗，大力协同、勇于登攀” 的 “两弹一星” 精神。[2] 


\section{1 “热爱祖国、无私奉献” ，是 “两弹一星” 精神的灵魂和精髓}

新中国成立之初, “面对新中国百废待兴、百业待举的困难局面, 一大批留学人员毅然 决然回到祖国怀抱, 在极其艰难困苦的条件下呕心沥血、顽强拼搏, 为新中国各项事业发展 奠定了坚实基础, 取得了 “两弹一星” 等举世瞩目的重大成就。” [3] 许多科学家宁愿放弃国 外优厚的条件, 毫不犹豫、义无反顾地回到祖国。许多研制工作者隐姓埋名, 默默奉献, 甘 当无名英雄, 有的甚至为此献出了宝贵的生命。他们 “献了青春献终身, 献了终身献子孙”, 用热血、青春和生命为祖国、为人民谱写了一部鞠躬尽瘁、死而后已的伟大的动人篇章。

“两弹一星” 功勋奖章获得者给我们留下了一个个动人的故事, 一句句感人肺腑的话语: 钱学森抛下国外优厚而又舒适的生活和工作条件, 冲破重重阻挠, 毅然决然回国; 王洤昌说 出了多年积压在他心头的一句话 “我愿以身许国”。[4]钱三强曾说 “我们当年背井离乡, 远 涉重洋到欧洲留学, 目的就是为了学到先进的科学技术, 好回去报效祖国”。[5]彭桓武在 英国获得两个博士学位后计划回国时, 有人问他为什么回国, 他说 “回国不需要理由, 不回 国才要理由”！ [6]

邓小平讲过：“如果六十年代以来中国没有原子弹、氢弹，没有发射卫星，中国就不可 能叫有重要影响的大国, 就没有现在这样的国际地位。” [7] 祖国今天的强大离不开这些科研 工作者的无私奉献。两弹一星科研工作人员用自己的行动诠释了爱国主义的内涵。他们的爱 国主义精神是社会主义价值观的最核心部分, 是实现中华民族伟大复兴的强大精神动力, 是 培养大学生核心价值观的力量源泉。

\section{2 “自力更生、艰苦奋斗” 是 “两弹一星” 精神的特征和标志}

建国初期，面对西方国家的压制或封锁政策，我们只能把目光投社会主义国家苏联。然 而, 苏联也企图向中国讲政治条件。毛泽东主席坚决地表示 “要政治条件, 连半个指头都不 行”。[8] 中国国防部第五研究院把 “以自力更生为主, 力争外援, 利用资本主义国家已有 的科研成果” 作为建院方针。[9] 正是坚持自力更生的方针, 中国逐步形成了一套自己的组 织和工作方法。当苏联单方面撕毁协定、撤走专家时, 我们的研究工作不但没有停顿, 反而 进一步健全了独立、完整的核工业体系。

广大 “两弹一星” 研制工作者在茫茫无际的沙漠戈壁, 在北风呼啸的雪山荒原, 在人烟 稀少的深山峡谷, 餐风露宿, 跋山涉水, 克服了重重难以想象的艰难险阻, 甚至经受住了生 命极限的考验。他们依靠有限的科研和试验条件, 突破了一个又一个技术难关, 取得了 “两 弹一星” 科研事业的伟大胜利。他们所具有的惊人毅力和勇气，显示了中华民族在自力更生、 艰苦奋斗的基础上屹立于世界民族之林的坚强决心和超凡能力。

\section{3 “大力协同、勇于登攀” , 是 “两弹一星” 精神的核心和本质}

建国初期，在极端艰难和艰苦的条件下，“两弹一星” 实验却在极短的时间内取得成功， 这是全国人民协同奋斗、科学家们勇于攀登科学高峰的结果, 是社会主义制度强大的凝聚力 的体现。1962 年 11 月 3 日毛泽东批示: “很好, 照办。要大力协同做好这件工作。” [10] 中央专门委员会是一个包括中央政治局、国务院、中央军委领导人的高度权威机构, 集指挥 权、财政权、人事权于一体，周恩来是这个权威机构的总指挥。[11] 在这种精神指导下，中 国核事业开始了新的征程, 全国成千上万的单位和个人大力协同展开攻坚战。他们这一支求 真务实、大胆创新的队伍, 突破了一系列关键技术, 攻克了一个个科学难关, 使我国的科研 能力实现了质的飞跃。他们用自己的勤劳智慧, 创造了一个个辉煌业绩, 为中华民族文明奋 斗史增添了光彩夺目的一页。

“两弹一星” 研制成功的事例是社会主义团结协作精神的完美体现, 它的实质是集体主 义。集体主义是社会主义核心价值体系不可缺少的重要组成部分。“两弹一星” 精神中的 “大 
力协同、勇于攀登” 精神，是实现中华民族伟大复兴的精神动力。

\section{3. “两弹一星” 精神在培育大学生社会主义核心价值观中的意义和作用}

\section{1 弘扬 “两弹一星” 精神, 加强当代大学生的理想信念教育}

远大的理想和坚定的信念是一个人的精神支柱和动力源泉。上世纪五六十年代, 在自然 条件和社会条件异常艰苦的环境中, 广大科研工作者仍然能取得巨大成功, 一个非常重要的 原因就是他们拥有远大的理想和坚定不移信念。加强当代大学生思想政治教育, 首先就要加 强大学生的理想信念教育。可以通过举行以 “两弹一星” 精神为主题的班会、专题讲座、专 题讨论、知识竞赛等活动, 加强大学生的马克思主义信仰教育, 树立社会主义信念教育, 使 当代大学生学会正确处理个人理想信念和国家前途命运的关系。要让这些学生明白, 只有坚 持社会主义制度, 坚持中国共产党的领导, 树立道路自信、理论自信和制度自信, 树立为实 现中国梦而努力奋斗的理想信念, 才能产生巨大的精神动力, 才能为建设祖国做出自己的贡 献。

\section{2 弘扬 “两弹一星” 精神，加强当代大学生的爱国主义教育}

从事 “两弹一星” 研究的科研人员中的大多数本来可以在国外过着优裕的生活, 但他们 怀着一颗炽热的爱国之心, 为了新中国的建设事业, 为了祖国的繁荣富强, 冲破重重障碍和 阻力, 毅然决然地回到祖国。“科学无国界, 但科学家都有自己的祖国”。[12] 几十年中, 他 们为了祖国的强大和人民生活的安定幸福而艰苦奋斗, 以惊人的毅力创造了人间奇迹, 如果 没有一颗炽热的爱国之心, 这些科研工作者们怎么能克服重重困难, 回到当时一贫二白、百 废待兴的新中国呢? “爱国主义是老一辈科学家献身国防的最大的精神动力, 是老一辈科学 家在两弹一星事业中艰苦奋斗、自力更生的力量源泉。” [13] 我们要弘扬 “两弹一星” 的精 神, 用爱国主义的思想教育当代青年大学生。要引导当代青年大学生以实现中国梦、振 兴中 华为己任, 必须把报国之志落实到自己的行动中, 树立主人翁意识, 从我做起, 从点滴做起, 积极投身到建设中国特色社会主义的伟大实践中, 为实现中华民族伟大复兴这一伟大梦想做 出自己的贡献

\section{3 弘扬 “两弹一星” 精神, 加强当代大学生的集体主义教育}

在研制 “两弹一星” 的过程中, 广大科研工作者精诚合作, 团结友爱, 充分发扬了集体 主义精神。这些科研工作者虽然来自五湖四海, 但为了一个共同的目标一一祖国的强大和民 族的振兴而走到一起。在重重困难面前, 他们表现出同甘共苦、同舟共济、友爱互助、生死 与共的集体主义精神。这种精神, 促使 “两弹一星” 研究集体凝聚成了一个具有强大战斗力 的团队和一个向心力极强的战斗集体。正是因为这种团结互助的集体主义精神, 广大科研工 作者才克服了重重困难，创造出举世瞩目的丰功伟绩。

社会主义核心价值体系的基本内容贯穿着集体主义价值观。[14] 在新的形势下，加强当 代大学生思想政治教育的重点内容之一就是加强大学生的集体主义教育。“两弹一星” 精神中 的团结互助的集体主义精神就是引导和帮助大学生树立正确的世界观、人生观、价值观的最 好的素材。用 “两弹一星” 事业中的协同精神教育当代学生, 让他们深刻理解 “两弹一星” 事业中广大研制人员为什么会有这样的团队协作精神, 引起他们从自我中走出来, 融入到 “大 我”的团队中去, 为社会主义现代化建设贡献力量。[15]

\section{4 弘扬 “两弹一星” 精神, 加强当代大学生的艰苦奋斗教育}

自力更生、艰苦奋斗精神，是 “两弹一星” 事业起步和发展的客观条件决定的，是 “两 弹一星” 事业坚定不移的基本方针。[16]正是因为有了自力更生、艰苦奋斗的伟大精神，广 大科研工作者才能不畏狂风暴沙, 不惧严寒酷暑, 在茫茫戈壁滩上, 在 “一无所有” 的情况 
下, 以惊人的速度和毅力从无到有、从小到大, 取得 “两弹一星” 的巨大的成功。我们要用 自力更生、艰苦奋斗、吃苦耐劳的精神教育当代大学生。要教育和引导他们树立艰苦创业的 意识, 教育和引导他们敢于正视困难, 不怕吃苦, 顽强拼搏, 树立社会责任感。要培养他们 自立自强的精神并拥有独立的人格, 磨练大学生不屈不挠的顽强意志。要教育和引导大学生 勇于到基层和艰苦的地方创业和就业, 用自己的知识本领和顽强的斗志，去开创新的事业。

\section{4.弘扬 “两弹一星” 精神, 培育当代大学生社会主义核心价值观的途径}

“两弹一星” 精神的内涵与社会主义核心价值观的实质的一致性以及 “两弹一星” 精神 对中国人民强烈的精神感召力, 使得在当代大学生中宣传 “两弹一星” 精神, 促进社会主义 核心价值观内化为大学生的价值体系成为可能。

\section{1 建设 “两弹一星” 精神的研究平台和宣传教育队伍}

一方面, 重视两弹一星研制历程相关知识的宣传, 根据学校地域优势, 汇合聚集研发力 量, 着力搭建研发平台。依托地区 “两弹一星” 研发遗址, 比如绵阳梓潼 “两弹一星” 城遗 址等, 组织研发力量, 建设 “两弹一星” 精神研究机构, 形成独具特色的两弹一星文化, 并 以此引领大学生进行参观或者参与到研究项目中, 切身体验 “两弹一星” 精神。这对传播正 能量和渗透主流意识来说, 是行之有效的措施。

另一方面，打铁还需自身硬。培养一支高素质 “两弹一星” 精神研究宣传工作者队伍， 是十分必要的。这支队伍, 包含两弹一星专家、学者, “两弹一星” 研发亲历者、见证者, 以 及高校学工、团委等职能部门和思想政治理论课教师、高校学生辅导员。这支队伍的成员既 有较高理论水平, 又掌握思想政治教育方法, 是对大学生进行两弹一星精神的熏陶和社会主 义核心价值观教育的基本保障。通过这支队伍, 可以准确了解青年大学生的思想动态, 及时 发现青年大学生关注的热点、难点问题, 尤其是苗头性、倾向性、群体性问题, 进而采取有 效合理的措施，有针对性地进行 “两弹一星” 精神和社会主义核心价值观的教育、引导。

\section{2 加强 “两弹一星” 精神文艺作品的创作和文化载体的建设}

要在大学生中大力宣传两弹一星精神, 那么创作大学生喜闻乐见的、能承载 “两弹一星” 精神的优秀文化艺术作品, 不失为一种很好的方式。弘扬 “两弹一星” 精神, 培育当代大学 生社会主义核心价值观, 需要优秀文化作品作为依托。电视连续剧《五星红旗迎风飘扬》、《国 家命运》《青海花儿》等, 就是这样的优秀作品。广大文艺工作者创作更多更优秀的文艺精品。 高校也可以充分发挥师生高知识层次、高文化素养的优势, 充分调动师生创作优秀文化作品, 生动具体地表现伟大的 “两弹一星” 精神和社会主义核心价值观, 让优秀文化作品润物细无 声地潜移默化滋润大学生的心田。使大学生在优秀文艺作品的熏陶中受到 “两弹一星” 精神 和社会主义核心价值观教育。

\section{3 占领思政课的主阵地和新媒体舆论宣传的战略高地, 加强 “两弹一星” 精神的宣传}

思政课是对大学生进行思想教育的主阵地。习近平强调思政课要用好课堂教学这个主渠 道, 思政课要在改进中加强, 以提升思政教育亲和力和针对性。高校思想政治教育要适应青 年大学生成长规律和身心特点, 创新思想政治理论课教育教学, 推动 “两弹一星” 精神和社 会主义核心价值观进教材、进课堂、进头脑。比如在《马克思主义基本原理概论》中讲述人 民群众是历史的创造者, 可列举两弹一星人 “大力协同、勇于登攀” 的事例, 进行集体主义 精神的教育; 在《毛泽东思想和中国特色社会主义理论体系概论》中, 可通过两弹一星人热 爱祖国, 无私奉献的精神, 结合中国特色社会主义理论和道路, 普及宣传 “两弹一星” 精神 和社会主义核心价值观; 在 《思想道德与法律基础》中, 结合两弹一星精神, 灌输自力更生 艰苦奋斗的精神。各高校还可以 “两弹一星” 研究方向, 组织 “两弹一星” 精神专题研究, 
以此推动大学生对 “两弹一星” 精神和社会主义核心价值观的学习、研究和宣传。

习近平强调 “要运用新媒体新技术使工作活起来, 推动思想政治工作传统优势同信息技 术高度融合，增强时代感和吸引力。” [17] 高校要充分发挥新媒体传播 “两弹一星” 精神和 社会社会主义核心价值观的主渠道作用。要加强 “两弹一星” 精神和社会主义核心价值观网 络阵地建设。新媒体传播阵地建设要以灵活多样的形式传播 “两弹一星” 精神和社会主义核 心价值观, 增强與论宣传感染力和渗透力。

\section{4 “两弹一星” 精神融入校园文化建设, 开展专题教育活动}

“只有将社会主义核心价值观具体化、案例化、形象化，才能避免在教育实践中的空洞 说教与无序灌输”。[18] 高校应结合自己学校的实际情况, 开展各种形式的的专题教育活动。 首先, 组织观看 “两弹一星” 题材的优秀影视作品或者请 “两弹一星” 亲历者、见证者为大 学生做报告, 使青年学生的心灵受到震撼; 其次, 组织和开展一些文娱活动, 比如小品、微 电影创作、“两弹一星” 主题演讲比赛等活动, 让学生在愉快的氛围中感受 “两弹一星” 精 神; 第三, 充分利用现有资源, 通过组织大学生参观 “两弹一星” 文物和遗址, 让静静的两 弹一星文物和遗址生动起来, 把 “两弹一星” 精神中最感人、最深刻、最具有教育意义的内 容以生动的形式呈现在当代青年大学生面前, 使之成为弘扬社会主义核心价值观和爱国主义 教育的有效载体, 让当代大学生在生动可感的活动中受到 “两弹一星” 精神的熏陶; 第四, 重视两弹一星研究开发重要纪念日, 比如第一颗原子弹、氢弹爆发的重要纪念日, 开展 “两 弹一星”爱国主义精神教育，弘扬民族精神，传播社会主义核心价值观。

\section{5. 结束语}

利用 “两弹一星” 精神培育大学生社会主义核心价值观, 加强对大学生理想信念教育、 爱国主义集体主义教育、自力更生艰苦奋斗教育, 具有重要的意义。“两弹一星” 精神是中华 民族伟大复兴宝贵的精神财富, 必须在大学生群体中间生根发芽, 使这一强大精神动力转化 为不可限量的物质创造力。通过多种途径, 弘扬 “两弹一星” 精神, 培育当代大学生社会主 义核心价值观, 加强高校思想政治工作和社会主义核心价值观教育, 促进 “两弹一星” 精神 内化为大学生的价值体系和自觉行动, 为实现 “两个一百年” 奋斗目标、实现民族复兴中国 梦提供有力人才支撑。

\section{致谢}

本文为绵阳师范学院 2012 年重点项目: 中国传统文化与马克思主义时代化关系研究, 编 号 2012B10; 绵阳师范学院高层次人才引进科研启动项目: 马克思主义三化与传统文化关系 研究, 编号 QD2012B04, 阶段性成果之一。

\section{References}

[1] Inherit the red gene and cast the spiritual Highland [J]. The life of CPC in Qinghai ,2016,12:61.

[2] Ren Zhen,Make great efforts to cooperate with state-owned enterprises to cast spirit,[J]. Enterprise Civilization, 2017,8:60-63.

[3] Xi Jinping, Speech at the 100th anniversary celebration of the founding of the European Union [J]. China Scholars Abroad,2013,12:14-17.

[4] Meng Hong,Review the story of hero who honor the "two bombs and one satellite",[J]. Corpus of Party History,2017,8:23-36. 
[5] Ge Nengquan,Work hard for the strength of the motherland,[J]. China Nuclear Industry, 2013,2:60-63.

[6] Shu Yun,The revelation of the development course of China's missile nuclear weapons, [J]. General Review of the Communist Party of China, 2005,4:4-11.

[7] He Yunfeng, On the development idea of Mao Zedong in his later years. [J]. Journal of Henan University(Social Science)vol.57.3, pp. 8-14, 2017.

[8] Liu Youkun, The evolution of Chinese leaders' view of national interests ,[J]. Chinese Journal of Strategic Studies2017,4:182-197.

[9] Yang Xiaohong;LiuXudong,Relying mainly on self-reliance and striving for foreign aid as a supplement [J]. Journal of Southwest Minzu University(Humanities and Social Science)vol.25.6, pp. 435-439, 2004.

[10] Xu Yan,The " Two Bombs " decision is long lived. [J]. Chinese Cadres Tribune,2011,6:24-27.

[11] "Successful experience and Enlightenment to "Two bombs and one satellite" project,[J]. Contemporary China History Studies, vol.20.5, pp. 41-49, 2013.

[12] Sun Li,Philosophical thought on humanism spirit in "Two bombs and one satellite ". [J]. Journal of Inner Mongolia Normal University(Philosophy and Social Sciences Edition), vol.41.2, pp. 76-79, 2012.

[13] Li Xiaodan,On the patriotic thought of " Two bombs and one satellite " meritorious scientists. [J]. Science \& Technology Vision,2013,9:135.

[14] Tian Yongjing; Yan Wu'er,Strengthen the ideal and belief of college students with the education of red spirit [J]. Leading Journal of Ideological \& Theoretical Education,2016,2:134-137.

[15] Dai Yanli,On the importance of " Two bombs and one satellite" cooperation spirit to strengthen the consciousness of teamwork of contemporary college students. [J].China Electric Power Education, 2011,11:157-158.

[16] Wang Chunhe,"Two bombs and one satellite" spirit: powerful spiritual motivation, [J]. Defence Science \& Technology Industry,2013,8:17-19.

[17] Zhao Cui Lin, A Study of the Predicaments and Solutions of the Discourse Power of the Ideological and Political Work in We-Media Era,[J]. Journal of Northeast Normal University(Philosophy and Social Sciences),vol.292.2, pp. 66-71, 2018.

[18] Ji Weibing,Shang Wenhao,The Way and Strategy of Cultivating Innovative Talents in Colleges and Universities with Military Culture [J]. Modern Education Science, 2017,6:90-94. 